\title{
Liquidity and Asset Pricing: Evidence from Indian Stock Market
}

\author{
Sharad Nath Bhattacharya \\ Associate Professor \\ Indian Institute of Management, Shillong, India \\ E-mail: snb@iimshillong.ac.in \\ Mousumi Bhattacharya \\ Assistant Professor \\ Indian Institute of Management, Shillong, India \\ E-mail: msb@iimshillong.ac.in \\ Sumit Kumar Jha \\ Research Fellow \\ Indian Institute of Management, Shillong, India \\ E-mail: sumit.fpmI4@iimshillong.ac.in
}

\begin{abstract}
In this research article, we present a liquidity premium based asset pricing model and test it in the Indian stock market. Using high-frequency data of stocks listed in the National Stock Exchange, we show that observed illiquidity has a significant negative impact on realized stock returns even after controlling for the up and down market, volatility, and effects of derivatives trading. The illiquidity measure is modified for its time variations, and then the modified measure is used to assess its impact on returns. Using a cross-section of stocks, we show the year wise results of the model and extend it to show that it has some role in explaining returns across industries. Findings show that the down market has contemporaneous systematic risk at higher levels, and the market risk premium is higher in down markets. Finance, utility and real estate sector companies have higher systematic risk in both up and down market and investors of these sectors has relatively higher expected higher returns in comparison to companies from the rest of the segments.
\end{abstract}

Keywords: Asset Pricing, Down Market, Illiquidity Measure, Liquidity Risk, Liquidity Premium, Stock Market.

JEL Classifications: GI0, GI2.

\section{Introduction}

Liquidity is an underlying concept without a universal definition. The most accepted notion of liquidity is the capability of an asset to trade in a market with minimal price disruption. A liquid market is expected to have a considerable number of orders both sides, i.e. above and below the last traded price of an asset. Investors of an illiquid asset face illiquidity risk, which is the possible inability to exit from the investment without incurring significant transaction costs. Risk-averse investors are expected to demand an illiquidity premium to undertake such illiquidity risk and invest in illiquid assets. Hence return on any asset is expected to include some illiquidity premium.

In a seminal work (Amihud \& Mendelson, 1986) found that excess returns include a premium for the quoted spread (bid-ask spread divided by price) at a declining rate, thus emphasizing a concave relationship due to clientele effect. Datar et al. (1998) evidence that liquidity proxies like trading volume explains stock returns and conclude that the relationship between the size of an asset and the return generated out of that asset reflects the relationship between liquidity and return. Garleanu \& Pedersen (2007) and Brunnermeier \& Pedersen (2009) supported the idea that there is an asymmetric influence of illiquidity on different states of the market. They supported this on the grounds of liquidity tremors, margin-induced price spirals, and tighter risk management by institutions. Garleanu \& Pedersen (20II) noted the importance of funding constraints in influencing risk and return dynamics. Hameed et al. (2010) evidenced that enormous negative returns have a stronger relationship with variations in liquidity measures than positive market returns. It is argued that liquidity premium is dependent or conditional upon the state of return, and an investor is asymmetrically concerned about liquidity during periods of positive and negative returns.

A market participant is more worried about the informational role of illiquidity during periods of negative returns for asset pricing than the periods of positive returns. Alternative theories supporting critical roles of illiquidity in explaining asset returns generally lay their foundation on supply-side arguments. Proponents of supply-side arguments evidence that during negative returns, the financial intermediaries especially market makers are impacted by their margin constraints due to a reduction in the value of the collaterals forcing them to liquidate their position and inducing an illiquidity spiral. Liquidity measures also suffer from the day of the week effect, month effect, holiday effect, and are also affected by global 
or local events (Chordia et al., 200Ia). Chordia et al. (200Ib) studied the time variations in liquidity, and they foresighted the role of unexpected liquidity in asset pricing models. They stressed the importance of understanding of nature of the relationship between liquidity and stock returns to improve the level of market participant's confidence in the stock market. Acharya \& Pederson (2005) showed that liquidity risk is priced. They argue that both individual stock level and marketlevel liquidity have significant explanatory power in predicting stock returns and an adverse shock to a stock's liquidity leads to lower realized return.

It is debated that measures of liquidity may have some influence in determining the level of liquidity of firms as well as of markets of different asset classes. The transaction cost-related measures like bid-ask spreads look for order processing, and execution costs present in the markets. In contrast, volume-based measures capture the number of trades or trading volume and try to understand the depth and breadth of the markets. The price impact measures changes in prices caused by the sudden changes in volume or imbalance of orders in the market. The effect of the arrival of new information is captured by the measures of resiliency. Some measures are more suitable for low-frequency data while others are more robust when they are constructed using high-frequency data. Across the choices available (Amihud, 2002) measure of illiquidity is one of the most widely used measures across both the emerging and developed markets. Ahn et al. (2018) provide a good summary of various liquidity measures available in the literature and document those influential in explaining stock returns in emerging markets.

This research article evidences the contemporaneous relationship between Indian security returns and illiquidity factor. The association exists even after controlling for local and global factors that are expected to influence stock returns. Over the past decade, the social and economic prospects of India have improved, and it is not only one of the fastest-growing economies but also has one of the largest stock markets in the world. We use 30 minutes of stock price data, and we show that stock prices have a contemporaneous relation with market return, illiquidity, open interest, and volatility. We modify the illiquidity measure of (Amihud, 2002) for time-varying effects and show that unexpected illiquidity negatively impacts stock return in the Indian market. We evidence that market premium is higher during down market compared to up markets. We also show that an increase in volatility does not necessarily lead to an increase or decrease in coefficient of market risk premium (a measure of systematic risk) but an increase in open interest in the market increases in the coefficient of market risk premium.

The remainder of the research article is prepared as follows. In section 2, we discuss the relevant literature, while in section 3, we describe the data and methodology. Section 4 presents the results and findings. Section 5 concludes the paper.

\section{Literature Review}

In developed nations enormous amount of research on liquidity risk premium is available (Amihud \& Mendelson, 1986; Chordia et al., 200Ib; Acharya \& Pedersen, 2005) but the same for emerging nations are comparatively limited. Numerous authors evidenced a significant positive association between expected security returns and illiquidity in US markets (Datar et al., 1998; Amihud, 2002). Chordia et al. (200Ia) evidence that time-varying illiquidity has a negative effect on stock returns in the US. Using a price impact measure of liquidity (Amihud, 2002) finds that realized liquidity risk and expected returns are positively related. However, unanticipated illiquidity is negatively related to excess returns in the US. Easley et al. (2002) use volume and turnover as a measure of liquidity to support an adverse effect of liquidity on returns in developed stock markets. Pástor \& Stambaugh (2003) show that stocks with higher sensitivities to market liquidity have higher returns on US stock exchanges; thus, supporting that market liquidity is an essential factor in asset pricing. Extending the standard Capital Asset Pricing Model (CAPM) to include security-specific and market-level liquidity premiums (Acharya \& Pedersen, 2005) explain how liquidity variations result in low realized returns and high expected returns using the data of NYSE and AMEX. Lee (20II) shows that covariance of a stock's illiquidity and US market return hurts the expected return. Artikis (2018) showed that liquidity is a priced factor for asset pricing in the UK.

Findings for emerging markets often contrasts the conclusion from the developed markets. In a causality study across 27 emerging stock markets (Jun et al., 2003) observe higher market illiquidity does not always lead to a higher return. Dey (2005) notes that turnover, as a liquidity measure, positively affects stock returns in the emerging market, but it is no longer significant in developed markets. One of the issues with emerging markets is the availability of data for the construction of liquidity proxies, and most of the emerging markets are order-driven markets compared to their quote-driven peers in the developed world. Amihud (2002) build an illiquidity measure (AI) that uses the 'absolute value of the daily return-tovolume' ratio to capture the price impact of liquidity. This measure allowed the study of the time-series effects of illiquidity shocks on realized stock returns. Using AI (Bekaert et al., 2007) describe a negative return-illiquidity relationship in I8 emerging markets. Hearn (2010) reports the existence of illiquidity factor in stock markets of SAARC countries like Bangladesh, Pakistan, and India but not in Sri Lanka. However, he could not support any time trends or unexpected changes in illiquidity. Narayan \& Zheng (20II) conducted a study on the Chinese stock market. They found mixed results on the relationship between liquidity and returns. They observe a negative relationship between stock return and liquidity, but the negative relation is more rooted in the Shanghai stock exchange compared to the Shenzhen stock exchange. Lee (20II) and Liang \& Wei (20I2) added another dimension to the study of illiquidity-return nexus in emerging markets where they supported a more significant role of local illiquidity risk in emerging stock markets. In developed markets, they argued that global illiquidity risks outweigh local illiquidity risk. Existence of more substantial illiquidity premium in the emerging 
markets compared to their developed peers are reported by (Amihud et al., 2015). Bhattacharya et al. (2016) report that multiple dimensions of liquidity collectively explain variations in the Indian stock market. Bhattacharya et al. (2019) report that market liquidity and returns exhibit both long-term and short-term relationships in India and added that trading activity and market resiliency (measured by market efficiency coefficient) affect the stock market positively while the spread has a negative influence on returns. Kumar \& Mishra (2019) provide empirical results of (Acharya \& Pedersen, 2005) model. They used (Fama \& MacBeth, 1973) regression in the Indian context and shows that liquidity is a priced factor in Indian Market. Stereńczak et al. (2020) investigated the influence of the absence of liquidity across frontier markets which are expected to be less integrated with other markets. They used a battery of liquidity proxies and covered both pre and post-global financial crisis period to conclude that there is no liquidity premium for investors investing in those stock markets. This finding is contrary to those observed in developed and emerging financial markets.

The present work extends the earlier studies in the Indian context. We build the daily measures of return and illiquidity using high-frequency firm-level data of the stocks consisting of the NIFTY500 to investigate the impact of illiquidity on returns during both up and down markets. We remove the time-varying components of AI to use the modified version of $\mathrm{AI}\left(\mathrm{AI} .^{\mathrm{m}}\right)$ in the presence of global liquidity factors like market volatility (vix) and open interest as advocated by (Donadelli \& Prosperi, 2012) in explaining stock returns.

\section{Data and Methodology}

The firms covered in the NIFTY 500 index for 2008 to 2017 were considered. The average return for each day for each stock is computed by aggregation of fourteen 30 minutes return for each day. The daily $\mathrm{AI}_{i}$ is constructed using the relation $A \mathrm{I}_{i}=$ Average $\left(\mathrm{r}_{\mathrm{t}} / \mathrm{V}_{\mathrm{t}}\right)$, where $r_{t}$ denotes return on stock on day $\mathrm{t}$ and $V_{t}$ represents the volume of the stock (in INR) traded in the National Stock Exchange on day t. The modified version of (Amihud, 2002) measure $\left(\mathrm{AI}^{\mathrm{m}}\right)$ is obtained as a residual of the equation I after controlling for the day of the week, month, holiday, and other critical financial events.

$$
\mathrm{AI}_{\mathrm{i}, \mathrm{t}}=\sum_{k=1}^{4} \mathrm{~d}_{\mathrm{i}, \mathrm{k}} \cdot \mathrm{D}_{\mathrm{k}, \mathrm{t}}+\sum_{\mathrm{k}=1}^{11} \mathrm{e}_{\mathrm{i} \cdot \mathrm{k}} \cdot \mathrm{M}_{\mathrm{k}, \mathrm{t}}+\beta_{1, \mathrm{i}} \cdot \mathrm{H}_{\mathrm{t}}+\beta_{2, \mathrm{i}} \cdot \mathrm{DCY}+\beta_{3, \mathrm{i}} \cdot \mathrm{SP}_{\mathrm{t}}+\beta_{4, \mathrm{i}} \cdot \mathrm{AT}_{\mathrm{t}}+\mathrm{AI}_{\mathrm{i}, \mathrm{t}}^{\mathrm{m}}
$$

As regressors, we considered weekday dummies ( $\left.\mathrm{D}_{\mathrm{k}, \mathrm{t}}\right)$; month dummy $\left(\mathrm{M}_{\mathrm{k}, \mathrm{t}}\right)$; weekends or holiday dummy $\left(\mathrm{H}_{\mathrm{t}}\right)$; time trend variables $\left(\mathrm{DCY}_{\mathrm{t}}\right.$ and $\left.\mathrm{SP}_{\mathrm{t}}\right)$. DCY $\mathrm{t}$ variable is introduced to capture the impact of DotCom mania (Ofek \& Richardson, 2003) that resulted in significant regulatory changes with time. DCY $t$ is calculated as the difference between the current calendar year and the year 2000 (dotcom year). The year 2000 is replaced by the year of listing for a stock if it was not listed in 2000. $\mathrm{SP}_{\mathrm{t}}$ is expected to capture the impact of the sub-prime crisis and is calculated as the difference between the current year and the year 2008 (replaced by the year of listing for those stocks not listed in 2008). Algorithmic trading $\left(A T_{t}\right)$ is allowed to capture the effect of algorithmic trading started at NSE on 4th April 2008. The residual $\mathrm{AI}_{\mathrm{i}, \mathrm{t}}^{\mathrm{m}}$ is interpreted as abnormal or unexpected illiquidity, which is existing in the stock market. Next, we run our asset pricing model as pooled OLS:

$$
\begin{aligned}
\mathrm{R}_{\mathrm{i}, \mathrm{t}}-\mathrm{R}_{\mathrm{f}, \mathrm{t}}=\alpha_{\mathrm{i}} & +\beta_{\mathrm{i}, \mathrm{m}}\left(\mathrm{R}_{\mathrm{m}, \mathrm{t}}-\mathrm{R}_{\mathrm{f}, \mathrm{t}}\right)+\beta_{\mathrm{i}, \mathrm{down}}\left(\mathrm{R}_{\mathrm{m}, \mathrm{t}}-\mathrm{R}_{\mathrm{f}, \mathrm{t}}\right) \cdot \mathrm{D}_{\text {down i,t }}+\beta_{\mathrm{i}, \mathrm{up}}\left(\mathrm{R}_{\mathrm{m}, \mathrm{t}}-\mathrm{R}_{\mathrm{f}, \mathrm{t}}\right) \cdot \mathrm{D}_{\mathrm{up} \mathrm{i,t}}+\gamma_{\mathrm{i}} \cdot \mathrm{AI}_{\mathrm{i}, \mathrm{t}-1}^{\mathrm{m}} \\
& \left.+\theta_{\mathrm{i}, \mathrm{m}}\left[\left(\mathrm{R}_{\mathrm{m}, \mathrm{t}}-\mathrm{R}_{\mathrm{f}, \mathrm{t}}\right) \cdot \mathrm{C}_{\mathrm{vix}, \mathrm{t}}\right]+\varphi_{\mathrm{i}, \mathrm{m}}\left[\left(\mathrm{R}_{\mathrm{m}, \mathrm{t}}-\mathrm{R}_{\mathrm{f}, \mathrm{t}}\right) \cdot \mathrm{C}_{\mathrm{o}, \mathrm{i}, \mathrm{t}}\right] \ldots \text { (II }\right)
\end{aligned}
$$

$R_{i, t}-R_{f, t}$ is the excess return over risk-free rate while $R_{i, t}-R_{f, t}$ represents the market risk premium. The risk-free rate is the annualized treasury bill rate applicable at time t. Based on the suggestion of (Donadelli \& Prosperi, 20I2) open interest and volatility index are included as the two global liquidity factors. Open interest is the number of outstanding derivatives contracts for options or futures contracts that have not been settled on the National Stock Exchange. Both the open interest (oi) and volatility index (vix) values for the Indian Stock Market are obtained from Bloomberg. $\mathrm{C}_{\mathrm{vix}, \mathrm{t}}$ and $\mathrm{C}_{\mathrm{oi}, \mathrm{t}}$ denotes changes in vix and oi respectively from period $\mathrm{t}-\mathrm{I}$ to $\mathrm{t}, \mathrm{D}_{\text {down }} \mathrm{i,t}$ and $\mathrm{D}_{\text {up i, }}$ denotes dummy variables to accommodate asymmetry. The dummy variable $D_{\text {down } i, t}\left(D_{\text {up } i, t}\right)$ is $I$ if the $R_{i, t}$ is less (more) than $I .5$ standard deviation of its unconditional mean. For the remaining values of $R_{i, t}$, the dummy variables value is 0 (neutral market).

\section{Result}

The findings are presented in Table I and Table II that reports market risk premium coefficients in three market scenarios (down, neutral, and up) through $\beta$ down, $\beta$, and $\beta$ up respectively where all three are statistically significant. The, $\beta+$ $\beta$ down $(\beta+\beta$ up $)$ represents the estimate of the sensitivity towards the market risk premium in Down $\left(\mathrm{Up}_{\mathrm{p}}\right)$ market. 
Table I. Year-wise parameter estimates of equation II

\begin{tabular}{|c|c|c|c|c|c|c|c|}
\hline Year & $\alpha$ & $\beta$ & $\beta$ up & $\boldsymbol{\beta}$ down & $\boldsymbol{\theta}$ & $\varphi$ & $\gamma$ \\
\hline All & 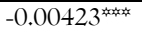 & 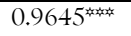 & $0.1025^{\text {and }}$ & $1.5^{\ldots}$ & $0.0454^{2}$ & II.I0 & $-0.3 \mathrm{I} 34^{2}$ \\
\hline Years & {$[0.000 \mathrm{I}]$} & {$[0.0017]$} & {$[0.002]$} & {$[0.0019]$} & {$[0.037]$} & {$[0.0482]$} & {$[0.065]$} \\
\hline \multirow[t]{2}{*}{2008} & $-0.0187^{-}$ & $0.8036^{2}$ & $-0.1138^{-4}$ & $1.314^{4}$ & $-0.0365^{2}$ & $9.119^{\prime}$ & $-0.3652^{* *}$ \\
\hline & {$[0.0005]$} & {$[0.0064]$} & {$[0.0088]$} & {$[0.007 \mathrm{I}]$} & {$[0.01]$} & {$[0.1394]$} & {$[0.2172]$} \\
\hline \multirow[t]{2}{*}{2009} & $-0.0097^{* \ldots}$ & $0.896^{2}$ & $-0.1682^{2}$ & I. $4855^{\ldots}$ & $-0.1086^{* \ldots+2 x}$ & 13.2908 & $-0.208^{\text {竟 }}$ \\
\hline & {$[0.0003]$} & {$[0.004]$} & {$[0.0052]$} & [0.0047] & {$[0.0181]$} & {$[0.1172]$} & {$[0.0967]$} \\
\hline \multirow[t]{2}{*}{2010} & $0.0044^{2}$ & 1.0712 & $0.237 I$ & I.5665 & $-0.087^{-1}$ & II.303I & $1.4474^{*}$ \\
\hline & {$[0.00 \mathrm{II}]$} & {$[0.0147]$} & {$[0.0153]$} & {$[0.015]$} & {$[0.0165]$} & {$[0.3981]$} & {$[0.7476]$} \\
\hline \multirow[t]{2}{*}{2011} & $0.0054^{2}$ & $1.0867^{*}$ & $0.3 \mathrm{I} 47$ & $1.5806^{2}$ & 0.0132 & 12.2402 & $-1.2353^{2}$ \\
\hline & {$[0.001]$} & {$[0.0118]$} & {$[0.0126]$} & {$[0.012]$} & {$[0.0144]$} & {$[0.3178]$} & {$[0.3425]$} \\
\hline \multirow[t]{2}{*}{2012} & $-0.00 \mathrm{I}$ & $1.0005^{\prime}$ & $0.2182^{\ldots}$ & I. .5384 & 0.02 & 9.8357 & 0.1912 \\
\hline & {$[0.0014]$} & {$[0.0166]$} & {$[0.017 \mathrm{I}]$} & {$[0.0169]$} & {$[0.0155]$} & {$[0.4582]$} & {$[0.2725]$} \\
\hline \multirow[t]{2}{*}{2013} & $-0.0057^{-}$ & $0.9485^{\ldots}$ & $0.1419^{\ldots}$ & I.5029 & $0.058 \mathrm{I}$ & $10.3473^{\text {and }}$ & $-0.416^{\ldots}$ \\
\hline & [0.0007] & {$[0.009]$} & {$[0.0095]$} & {$[0.0094]$} & {$[0.0153]$} & {$[0.2717]$} & {$[0.207]$} \\
\hline \multirow{2}{*}{2014} & $0.0083^{2}$ & I.III5 & $0.3351^{2}$ & $1.6332^{2}$ & $-0.0878^{-1}$ & $\mathrm{I} 2.6862^{2}$ & $-0.120 \mathrm{I}$ \\
\hline & [0.0012] & {$[0.0146]$} & [0.015] & [0.0147] & {$[0.0126]$} & {$[0.4212]$} & {$[0.3023]$} \\
\hline \multirow[t]{2}{*}{2015} & $0.0145^{2}$ & $1.206^{\prime}$ & $0.3388^{\text {and }}$ & $1.7472^{\prime}$ & 0.0215 & 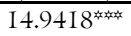 & $-2.433 \mathrm{I}$ \\
\hline & {$[0.0013]$} & {$[0.017 \mathrm{I}]$} & {$[0.0177]$} & {$[0.0176]$} & {$[0.0148]$} & {$[0.494]$} & {$[1.577]$} \\
\hline \multirow[t]{2}{*}{2016} & $0.0073^{\text {x }}$ & I.II73 & 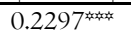 & I.6802 & -0.0088 & I3.0725 & $-56.3764^{4}$ \\
\hline & [ 0.0007$]$ & {$[0.0092]$} & {$[0.01]$} & {$[0.0096]$} & {$[0.0169]$} & {$[0.3355]$} & {$[\mathrm{I} 3.5369]$} \\
\hline \multirow[t]{2}{*}{2017} & 0.0163 & $1.2623^{\text {列 }}$ & 0.2728 & I.97I & $0.2209^{\prime}$ & $18.9006^{1}$ & 3.7834 \\
\hline & {$[0.0012]$} & {$[0.018]$} & {$[0.0186]$} & {$[0.0184]$} & {$[0.0248]$} & {$[0.7568]$} & {$[\mathrm{I} 3.53 \mathrm{I}]$} \\
\hline
\end{tabular}

Table I shows that $\mathrm{AI}^{\mathrm{m}}$ co-efficient $\gamma$ is significant and negative considering the entire period. By assuming that there is no association between market liquidity and corporate cash flow, it is established that unexpected illiquidity $\left(\mathrm{AI}^{\mathrm{m}}\right)$ has an adverse influence on equity returns. Following (Amihud, 2002) we maintain that observed illiquidity raises expected illiquidity. Furthermore, the compensation for an investor who accepts this expected illiquidity is reflected in higher expected returns and lower contemporaneous stock prices for the investors. Downmarket beta $(\beta+\beta$ down $)$ is consistently higher than upmarket beta $(\beta+\beta$ up $)$ in all the years. The down market has contemporaneous systematic risk at a higher level (measured by beta). This higher beta would lead to higher expected returns as investors would get into the market at lower levels (down market), making expected returns higher on the recovery of the market. The upmarket beta was lower than neutral beta during 2008 and 2009. It appears that pre-emptive actions by market regulators like SEBI and RBI have some role in reducing the systematic risk during that time (subprime crisis and its aftermath). The yearly trends of varying marketing risk premium coefficient (beta) in different market conditions in the presence of the illiquidity factor is presented in Figure I. Global liquidity factors coefficients $\theta(\varphi)$ is small (large), positive, and significant for the overall period. $\Phi_{\text {vix }}$ turns negative and significant in 2008,2009, and 2010 - that coincides with the years of government policy paralysis under the UPA-II regime in India.

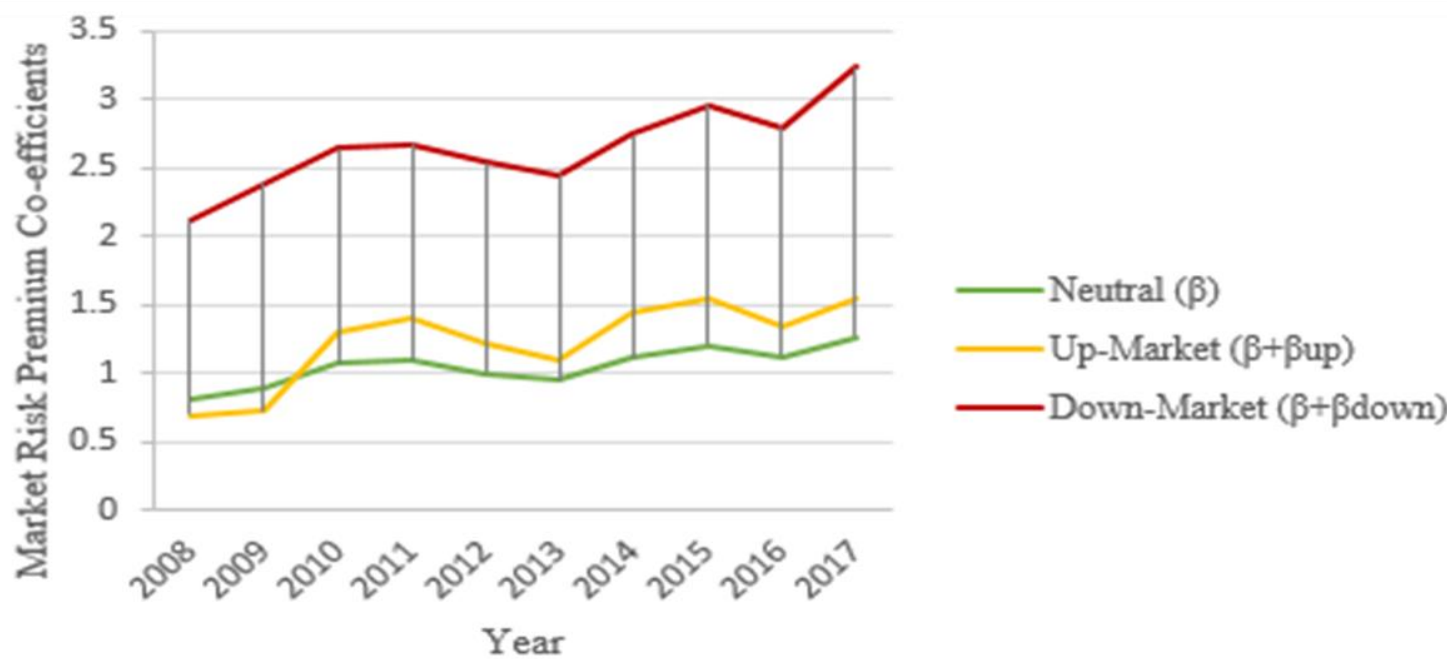

Figure I. Trends of market risk premium sensitivity 
Next, we present the estimates from equation II for industries.

Table 2. Sector-wise parameter estimates of equation II

\begin{tabular}{|c|c|c|c|c|c|c|c|}
\hline Sector & A & $\beta$ & Bup & $\beta$ down & $\Phi_{\text {vix }}$ & $\Phi_{\text {oi }}$ & $\gamma$ \\
\hline \multirow[t]{2}{*}{$\mathrm{CD}$} & $-0.0062^{2}$ & $0.94 I^{\prime}$ & $0.0627^{2}$ & $1.4939^{\text {and }}$ & $0.0597^{x}$ & II.452I & $-0.5116^{2}$ \\
\hline & {$[0.0003]$} & {$[0.0044$} & {$[0.005 \mathrm{I}]$} & {$[0.0049]$} & {$[0.0094]$} & {$[0.1221]$} & [0.1 I8I \\
\hline \multirow[t]{2}{*}{$\mathrm{CS}$} & $-0.0117^{-2 x}$ & $0.8658^{2 x}$ & $0.0139^{\text {* }}$ & $1.4245^{\text {s. }}$ & $0.0522^{x}$ & $10.7922^{2}$ & $0.2047^{\text {*x }}$ \\
\hline & {$[0.0005]$} & {$[0.0062]$} & {$[0.0074]$} & {$[0.007 \mathrm{I}]$} & {$[0.0134]$} & {$[0.1687]$} & {$[0.1133]$} \\
\hline \multirow[t]{2}{*}{ ENR } & -0.0009 & $1.0038^{2}$ & $0.1607^{2}$ & I.504 & 0.0206 & $10.7814^{2}$ & 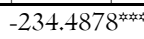 \\
\hline & {$[0.0007]$} & {$[0.009]$} & {$[0.0114]$} & {$[0.0104]$} & {$[0.0196]$} & {$[0.2525]$} & {$[80.8294]$} \\
\hline \multirow[t]{2}{*}{ FIN } & 0.0004 & $1.0216^{2}$ & $0.2015^{x}$ & $1.5088^{\text {and }}$ & $0.0444^{2}$ & 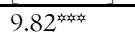 & $-2.653^{\text {thex }}$ \\
\hline & {$[0.0003]$} & {$[0.004]$} & {$[0.005]$} & {$[0.0046]$} & {$[0.009]$} & {$[0.1127]$} & {$[0.6506]$} \\
\hline \multirow[t]{2}{*}{$\mathrm{HC}$} & -0.0114 & $0.8692^{2}$ & $0.0138^{x+2}$ & $\mathrm{I} .44 \mathrm{I}^{\mathrm{A}}$ & $0.053 I^{2}$ & I I.5007 & 0.1803 \\
\hline & {$[0.0004]$} & {$[0.0058]$} & {$[0.007]$} & {$[0.0069]$} & {$[0.0126]$} & {$[0.1604]$} & {$[0.2682]$} \\
\hline \multirow[t]{2}{*}{ IND } & $-0.0029^{-2 x}$ & $0.9843^{\text {and }}$ & $0.120 I^{2}$ & 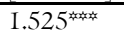 & $0.0425^{x}$ & II.6I42 & 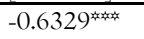 \\
\hline & {$[0.0004]$} & {$[0.0046]$} & {$[0.0055]$} & {$[0.0052]$} & {$[0.010 \mathrm{I}]$} & {$[0.1287]$} & {$[0.1426]$} \\
\hline \multirow[t]{2}{*}{ IT } & $-0.0079^{-2}$ & 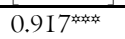 & $0.0369^{2}$ & $1.4783^{\text {列 }}$ & $0.0424^{x}$ & II.2432 & 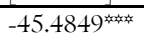 \\
\hline & {$[0.0005]$} & {$[0.0067$} & {$[0.008]$} & {$[0.0076]$} & {$[0.0146]$} & {$[0.1864]$} & [8.7994] \\
\hline \multirow[t]{2}{*}{ MAT } & $-0.0038^{2}$ & $0.9709^{2}$ & $0.0996^{2}$ & $1.494 \mathrm{I}^{\mathrm{d}}$ & $0.0577^{2}$ & II.4719 & -0.3229 \\
\hline & {$[0.0003]$} & {$[0.0042]$} & {$[0.005]$} & {$[0.0048]$} & {$[0.0091]$} & {$[0.1161]$} & {$[0.24]$} \\
\hline \multirow[t]{2}{*}{ RE } & 0.007 & I.II26 & $0.2303^{2}$ & $1.6733^{2}$ & $-0.1246^{\text {列 }}$ & $9.8929^{2}$ & 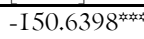 \\
\hline & {$[0.0009]$} & {$[0.0112]$} & {$[0.0132]$} & {$[0.012 \mathrm{I}]$} & {$[0.0246]$} & {$[0.3232]$} & {$[37.2249]$} \\
\hline \multirow[t]{2}{*}{ TEL } & $0.00 \mathrm{I}$ & I.04II & $0.1595^{x}$ & 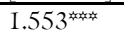 & 0.0003 & $10.517 \mathrm{I}^{2}$ & -21.023 \\
\hline & {$[0.0011]$} & {$[0.0139]$} & {$[0.0166]$} & {$[0.0156]$} & {$[0.0306]$} & {$[0.3901]$} & [6I.1635] \\
\hline \multirow{2}{*}{ UTIL } & $0.0022^{2}$ & I.0444 & $0.2298^{2}$ & $1.5323^{\text {and }}$ & 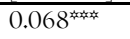 & $10.2193^{\text {an }}$ & 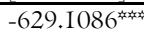 \\
\hline & {$[0.0006]$} & {$[0.0077]$} & {$[0.0096]$} & {$[0.0088]$} & {$[0.017]$} & {$[0.223]$} & {$[92.4152]$} \\
\hline
\end{tabular}

Sector-wise regression coefficient estimates presented in Table 2 reveal that Finance, utility, and real estate exhibits maximum systematic risk $(\beta)$ in normal market conditions. In an up-market too finance, utility and real estate sector have maximum $\beta+\beta$ up compared to other industries. Similarly, values of $\beta+\beta$ down reveal that in a down-market, investors of firms belonging to finance, industry, utility, telecom, and real estate sectors anticipate relatively higher returns in comparison to companies of the rest of eleven sectors. Therefore, investments in utility and real estate firms give better excess returns to all three market conditions. It may be noted here that Government is the majority shareholder in most of the utility companies. These are generally high dividend-paying companies, and they often play some role in reducing the fiscal deficit. The variation in risk premium can be visualized in figure 2 .

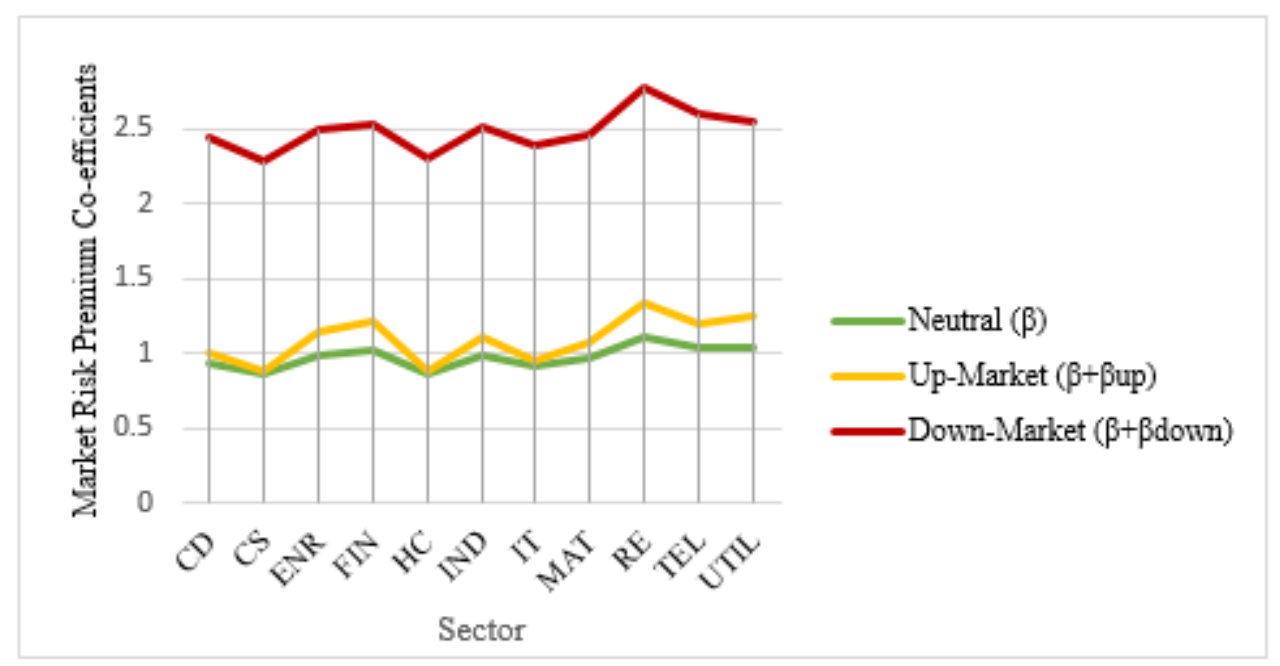

Figure 2. Trends of market risk premium sensitivities

Adjusted illiquidity co-efficient $\gamma$ is negative and significant for aggregated data and sectoral data; it is negative and significant for all but three sectors (HC, MAT, and TEL). The global illiquidity factors (oi and vix) are impacting returns in Indian stock market along with local liquidity parameter $(\gamma)$. At least one of the three is significant in each year and each industry. To understand the interaction between market risk premium (MRP or Rm-Rf) and global liquidity factors (volatility index and open interest), we draw "interplots" as shown in Figure 3. 

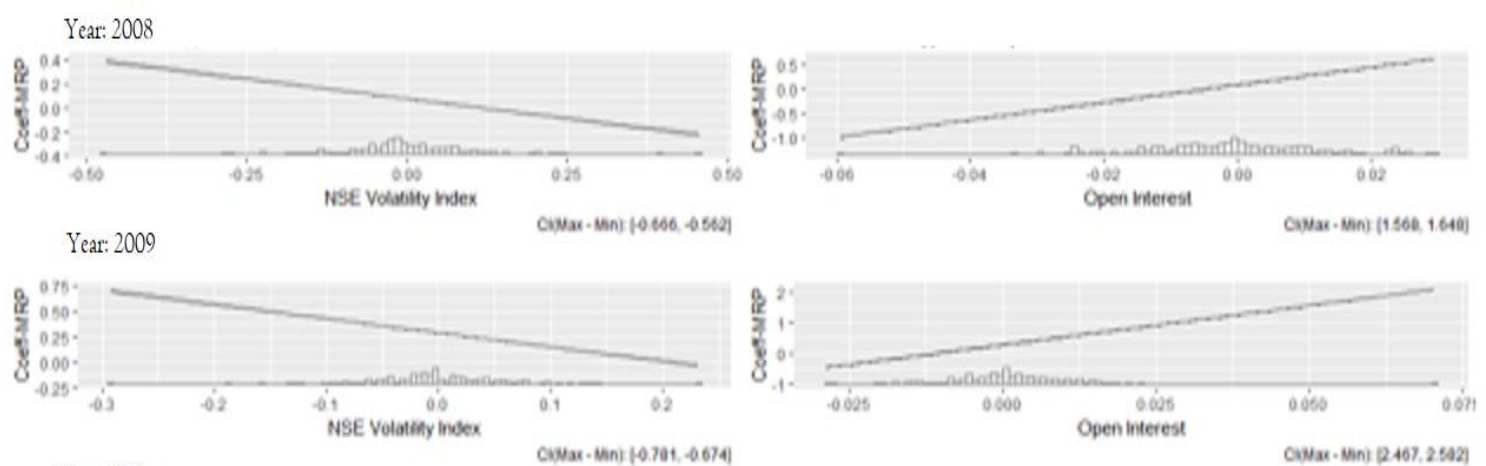

Year: 2010
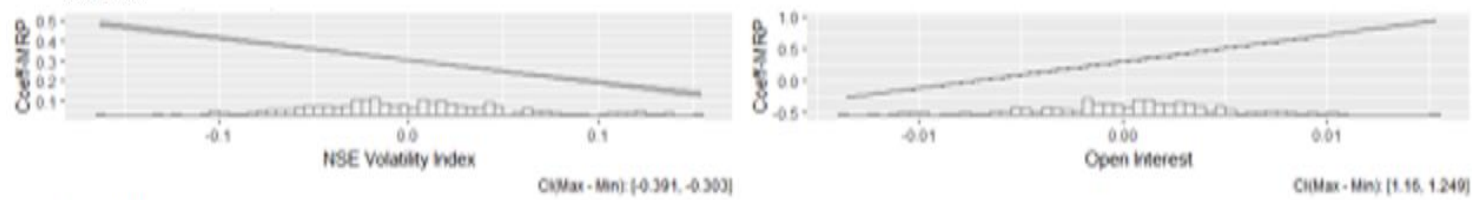

Year: 20II
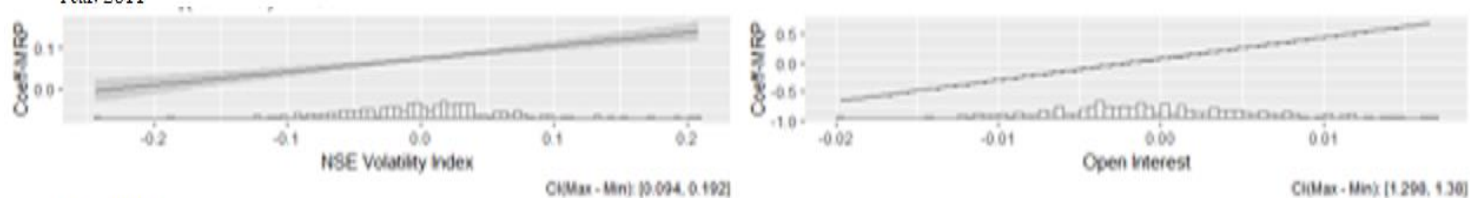

Year: $20 \mathrm{I2}$
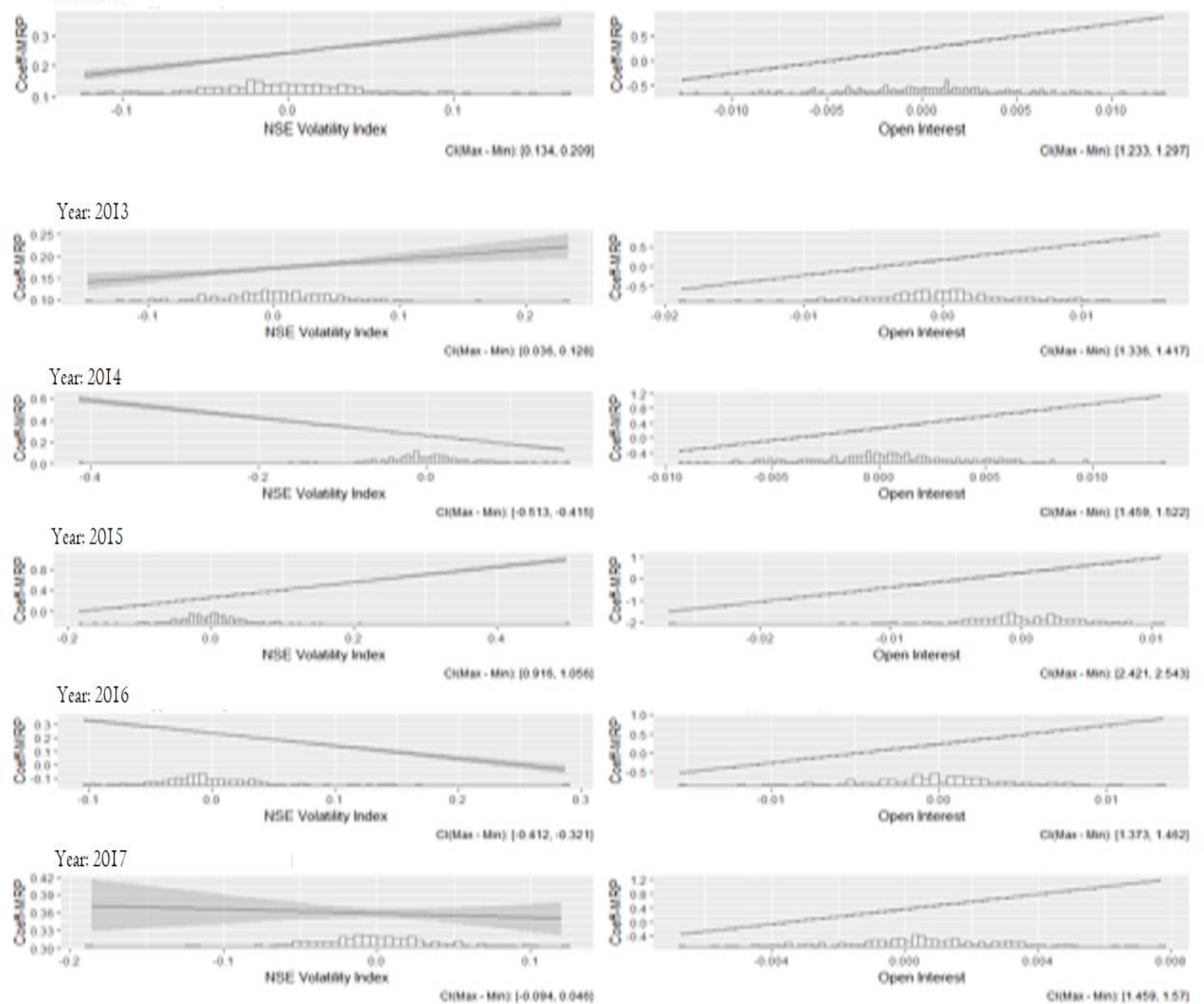

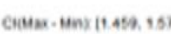

Figure 3. Interplot for an interaction effect between the coefficient of the market risk premium and "volatility" (left) and "open interest" (right) during 2008-2017 
An increase in volatility leads to a decrease in the coefficient of market risk premium during 2008-20I0, 20I4, and 2016. 2008-20I0 is the sub-prime crisis and recovery period from the crisis. In 2014 the Indian stock market experienced high volatility during the general election. 2016 was the year of regulatory changes about financial inclusion initiatives by the Government of India which culminated in demonization drive. Millions of Indians experienced banking for the first time during that period and banks used technology to reach a large number of customers in a short time. The findings are in line with (Ang et al., 2009) where they supported the presence of broad non-diversifiable factors behind the phenomenon. Supporting (Bhuyan \& Chaudhury, 2005; Fodor et al., 20I I) figure 3 reveals that an increase in open interest in the market positively impacts returns through the increase in the coefficient of market risk premium. Hence investors in the Indian stock market need to keep an eye on the changes in open interest in the Indian derivatives market as well as on changes in the volatility index.

\section{Conclusion}

The modified (Amihud, 2002) measure is significant in explaining stock market liquidity in the Indian context. It is successful in capturing variations in illiquidity fluctuations during periods of financial shocks like dotcom year, sub-prime crisis, and other India specific events. The realized excess stock returns are negatively related to contemporaneous illiquidity. In line with (Amihud, 2002) we argue that higher illiquidity or AI raises expected illiquidity in the Indian market resulting in lower stock prices. The negative impact of AI on excess return; i.e., significant and negative $\gamma$, in the Indian stock market, appears to be the largest in 2016- the year of financial inclusion drive by the Indian Government. The global illiquidity factors (volatility index and open interest) also impact returns in the Indian stock market. The interaction effect of changes in volatility index with market risk premium shows an increase in volatility leads to a decrease in coefficient of market risk premium, especially during periods of exogenous shocks. The open interest impacts excess returns positively. The downmarket systematic risk is consistently higher than neutral and up-market systematic risks. Across sectors, finance, industry, utility, telecom, and real estate has a higher systematic risk and thus higher expected return for investors in these sectors.

Modified (Amihud, 2002) measure and consideration of this measure in portfolio construction strategies may help investors make better investment decisions. The study provides enough support in the lines of (Claessens et al., 2012) and advocates liquidity-based asset pricing models for the financial markets. A further investigation into the different networks of liquidity risk after considering a large number of stocks for a relatively long period across different countries can give a possible future direction of research.

\section{References}

Acharya, V. V., \& Pedersen, L. H. (2005). Asset pricing with liquidity risk. Journal of financial Economics, 77(2), 375 410.

Ahn, H. J., Cai, J., \& Yang, C. W. (2018). Which liquidity proxy measures liquidity best in emerging markets?. Economies, 6(4), I-29.

Artikis, P. G. (2018). Liquidity as an asset pricing factor in the UK. Journal of Financial Management, Markets and Institutions, 6(2). https://doi.org/I0.I I42/S22827I7XI850008I

Amihud, Y. (2002). Illiquidity and stock returns: cross-section and time-series effects. Journal of financial markets, 5(I), 3I-56.

Amihud, Y., \& Mendelson, H. (1986). Asset pricing and the bid-ask spread. Journal of financial Economics, I7(2), 223 249.

Amihud, Y., Hameed, A., Kang, W., \& Zhang, H. (2015). The illiquidity premium: International evidence. Journal of Financial Economics, II $7(2), 350-368$.

Ang, A., Hodrick, R. J., Xing, Y., \& Zhang, X. (2009). High idiosyncratic volatility and low returns: International and further US evidence. Journal of Financial Economics, 9I(I), I-23. https://doi.org/I0.IOI6/J.JFINECO.2007.I2.005

Bekaert, G., Harvey, C. R., \& Lundblad, C. (2007). Liquidity and expected returns: Lessons from emerging markets. The review of financial studies, 20(6), I783-I83I. https://doi.org/I0.1093/rfs/hhm030.

Bhattacharya, S. N., Bhattacharya, M., \& Basu, S. (2019). Stock market and its liquidity: Evidence from ARDL bound testing approach in the Indian context. Cogent Economics \& Finance, 7(I), 1586297. https://doi.org/I0.1080/23322039.2019.1586297

Bhattacharya, S. N., Sengupta, P., Bhattacharya, M., \& Roychoudhury, B. (2016). Multidimensional liquidity: Evidences from Indian stock market. Applied Finance Letters, 5(2), 28-44.

Bhuyan, R., \& Chaudhury, M. (2005). Trading on the information content of open interest: Evidence from the US equity options market. Derivatives Use, Trading \& Regulation, II(I), I6-36.

Brunnermeier, M. K., \& Pedersen, L. H. (2009). Market liquidity and funding liquidity. The review of financial studies, 22(6), 220I-2238.

Chordia, T., Roll, R., \& Subrahmanyam, A. (200I a). Market liquidity and trading activity. The journal of finance, 56(2), 50I-530.

Chordia, T., Subrahmanyam, A., \& Anshuman, V. R. (200Ib). Trading activity and expected stock returns. Journal of 
financial Economics, 59(1), 3-32.

Claessens, S., Kose, M. A., \& Terrones, M. E. (2012). How do business and financial cycles interact?. Journal of International economics, 87(I), I78-190.

Datar, V. T., Naik, N. Y., \& Radcliffe, R. (1998). Liquidity and stock returns: An alternative test. Journal of Financial Markets, I(2), 203-2I9.

Dey, M. K. (2005). Turnover and return in global stock markets. Emerging Markets Review, 6(I), 45-67.

Donadelli, M., \& Prosperi, L. (2012). On the role of liquidity in emerging markets stock prices. Research in Economics, 66(4), 320-348.

Easley, D., Hvidkjaer, S., \& O'hara, M. (2002). Is information risk a determinant of asset returns?. The journal of finance, 57(5), 2I85-222I.

Fama, E. F., \& MacBeth, J. D. (1973). Risk, return, and equilibrium: Empirical tests. Journal of political economy, 8I(3), 607-636.

Fodor, A., Krieger, K., \& Doran, J. S. (20I I). Do option open-interest changes foreshadow future equity returns?. Financial markets and portfolio management, 25(3), 265-280.

Garleanu, N., \& Pedersen, L. H. (2007). Liquidity and risk management. American Economic Review, 97(2), I93-I97.

Garleanu, N., \& Pedersen, L. H. (20I I). Margin-based asset pricing and deviations from the law of one price. The Review of Financial Studies, 24(6), I980-2022.

Hameed, A., Kang, W., \& Viswanathan, S. (2010). Stock market declines and liquidity. The Journal of finance, 65(I), 257-293.

Hearn, B. (2010). Time varying size and liquidity effects in South Asian equity markets: A study of blue-chip industry stocks. International Review of Financial Analysis, I9(4), 242-257.

Jun, S. G., Marathe, A., \& Shawky, H. A. (2003). Liquidity and stock returns in emerging equity markets. Emerging Markets Review, 4(I), I-24.

Kumar, G., \& Misra, A. K. (2019). Liquidity-adjusted CAPM-An empirical analysis on Indian stock market. Cogent Economics \& Finance, $7(\mathrm{I}), \mathrm{I} 57347 \mathrm{I}$.

Lee, K. H. (20I I). The world price of liquidity risk. Journal of Financial Economics, 99 (I), I36-I6I.

Liang, S. X., \& Wei, J. K. (2012). Liquidity risk and stock returns around the world. Journal of Banking \& Finance, 36(I2), 3274-3288.

Narayan, P. K., \& Zheng, X. (20II). The relationship between liquidity and returns on the Chinese stock market. Journal of Asian Economics, 22(3), 259-266.

Ofek, E., \& Richardson, M. (2003). Dotcom mania: The rise and fall of internet stock prices. The Journal of Finance, $58(3)$, III3-II37.

Pástor, L., \& Stambaugh, R. F. (2003). Liquidity risk and expected stock returns. Journal of Political economy, III(3), 642-685.

Stereńczak, S., Zaremba, A., \& Umar, Z. (2020). Is there an illiquidity premium in frontier markets?. Emerging Markets Review, 42, 100673.

\section{Copyrights}

Copyright for this article is retained by the author(s), with first publication rights granted to the journal. This is an openaccess article distributed under the terms and conditions of the Creative Commons Attribution license (http://creativecommons.org/licenses/by/4.0/). 